\title{
The Short-Term Reaction To The Dividend Tax Reduction
}

Richard H. Fosberg, (E-mail: fosbergr@wpunj.edu), William Paterson University

\begin{abstract}
With the passage of the Jobs and Growth Reconciliation Act of 2003, the maximum tax rate on dividend income was lowered from $38.6 \%$ to $15 \%$. This eliminated the traditional tax disadvantage that dividend income had relative to capital gains income. Theoretically, this should have led a significant number of firms to increase their dividend payments. In an empirical analysis of firm dividend payments after the dividend tax reduction took effect, it was found that there was a statistically significant increase in the number of firms raising their dividends. For example, in the third quarter of 2003, 4.6\% more firms increased their dividends than did so in the third quarter in 2002. Similarly, 4.9\% more firms increased their dividend payments in the fourth quarter of 2003 than did so in the fourth quarter of 2002. A logit regression analysis of dividend changes showed that most of the change in the number of dividend increases was caused by the dividend tax reduction and not other factors such as earnings, earnings stability, investment opportunities or firm size. The logit regression analysis also indicated that the dividend tax reduction increased by $3.7 \%$ $(4.2 \%)$ the probability that the average sample firm would increase its dividend payment in the third (fourth) quarter of 2003. It was also found that the greater a firm's blockholder share ownership the less likely the firm was to increase its dividend payment following the dividend tax reduction. CEO and other officer and director share ownership were found to be unrelated to the probability that a firm would increase its dividend payment.
\end{abstract}

\section{INTRODUCTION}

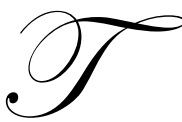

raditionally, the tax rate applicable to the dividend income received by taxable investors who own shares of common stock has been greater than the tax rate that applies to capital gains income earned on their stock investments. Consequently, as pointed out by Black (1976), a tax paying investor who wishes to "maximize his after-tax expected return" should generally "prefer smaller dividends, or no dividends at all." However, on May 28, 2003 when the Jobs and Growth Reconciliation Act of 2003 was signed into law, the traditional tax disadvantage of dividend income was eliminated. Under the Act, the maximum tax rate on dividend income was reduced from $38.6 \%$ to $15 \%$. Additionally, the top tax rate on capital gains income was also reduced from $20 \%$ to $15 \%$. With the elimination of the dividend tax disadvantage, the expected after-tax return on reinvested dividend income increases, making dividend income more valuable for taxable investors. Assuming that the majority a firm's stockholders are not tax-exempt, shareholder wealth maximizing managers should respond to the enhanced value of dividend income by reducing the amount of earnings invested within the firm and increasing the amount of dividends paid to shareholders.

Nevertheless, managers have personal financial incentives not to do so. For example, several empirical studies have shown that managerial compensation is strongly positively correlated with firm size (see Agrawal and Knoeber (1998) and Core, Holthausen, and Larcker (1999)). Greater firm size may also allow managers to consume more perks, diversify their personal investment portfolios, and/or enhance their professional status (see Jensen and Meckling (1976), Amihud and Lev(1981), and Fama and Jensen (1983)). Consequently, managers may prefer not to increase the firm's dividend payment so that firm size and their compensation, perks, etc. can be maximized. A survey of financial executives conducted by Brav, Graham, Harvey, and Michaely (2004) shortly after the passage of the Act lends support to this possibility. Brav, et al. found that only $30 \%$ of the financial executives of companies currently paying dividends probably or definitely would increase dividend payments as a result of the dividend tax reduction. ${ }^{1}$ 
Additionally, only $13 \%$ of financial executives of firms that currently do not pay a dividend said the dividend tax reduction would lead them to initiate dividend payments. These survey results suggest the managers of most firms will not respond to the dividend tax reduction by increasing their firm's dividend payments. This tepid response by financial executives to the dividend tax reduction occurred even though many financial executives realize shareholders value dividends. For example, Brav et al. found that $44.5 \%$ of financial executives think that paying dividends is an important or very important factor in attracting retail investors. An even higher percentage (52.5\%) think that paying dividends is an important or very important factor in attracting institutional investors.

The main focus of this study is to ascertain to what extent firms increased their dividend payments in response to the dividend tax reduction. In an empirical analysis of firm dividend payments after the dividend tax reduction took effect, it was found that there was a statistically significant increase in the number of firms raising their dividends. For example, in the third quarter of 2003 , $4.6 \%$ more firms increased their dividends than did so in the third quarter in 2002. Similarly, 4.9\% more firms increased their dividend payments in the fourth quarter of 2003 than did so in the fourth quarter of 2002. A logit regression analysis of dividend changes showed that most of the change in the number of dividend increases was caused by the dividend tax reduction and not other factors such as earnings, earnings stability, investment opportunities or firm size. The logit regression analysis also indicated that the dividend tax reduction increased by $3.7 \%(4.2 \%)$ the probability that the average sample firm would increase its dividend payment in the third (fourth) quarter of 2003. This relatively weak response to the dividend tax reduction could indicate that, in this instance, managers and directors did not vigorously pursue the interests of their firm's shareholders. It was also found that the greater a firm's blockholder share ownership the less likely the firm was to increase its dividend payment following the dividend tax reduction. CEO and other officer and director share ownership were found to be unrelated to the probability that a firm would increase its dividend payment.

The rest of the paper is organized as follows. Section I contains a discussion of the sample selection procedures used in this study and a discussion of the characteristics of the sample firms. In Section II, the empirical analyses used in this study are presented and their results interpreted. Section III contains a summary of the findings reported in this paper.

\section{DATA}

The base sample for this study are the firms contained in the S\&P 500 and S\&P MidCap 400 indices as listed in the 4-30-04 version of COMPUSTAT. From this group of firms, only companies listed on the NYSE or AMEX stock exchanges and whose fiscal year ends in December are included in the final sample. Benartzi, Michaely and Thaler (1997) have shown that firms are more likely to increase their dividends in the first and fourth quarters of their fiscal years, therefore, including firms with different fiscal years in the sample is likely to confound the effect of the dividend tax change. Firms in the financial services and utilities industries and that did not have data for their 2003 fiscal year available on COMPUSTAT were also eliminated from the sample. The final sample contains 348 firms. All accounting and financial data used in this study came from COMPUSTAT and all share ownership and leadership structure data came from proxy statements obtained from the SEC's EDGAR data base. The most recent proxy statement issued prior to July 1, 2003 was used to obtain the requisite share ownership and leadership structure data (except for 2 proxies from August 2003). The primary focus of this study will be on dividend changes that occurred in the third and fourth quarters of 2003, the first full quarters in which dividend payments could have been affected by the dividend tax reduction. Because the change in dividend taxation became law on May 28, 2003 it is possible that some firms, either after the tax change was signed or in anticipation that it would be, increased their dividends prior to July 1,2003 . To the extent that this occurred, the findings in this study will understate the effect of the dividend tax change on firm dividend payments.

Summary statistics for selected variables for the full sample of firms are presented in Table I. The sample firm's median total assets (Assets) and market value of common equity (MV Eq) are $\$ 3.709$ billion and $\$ 3.177$ billion, respectively. They also have a median total debt to total assets ratio (Debt) of .284. From 1993 to 2002, sales of the sample firms increased by a median $65.6 \%$ (Sales Growth). The sample firms were generally profitable, with a median annual earnings before extraordinary items per share (EPS) of \$1.33 in 2002. The median standard deviation of annual EPS from 1993 to 2002 was .791. The CEOs (chief executive officers) of the sample firms owned a median 
$.82 \%$ of their firm's common stock while all other officers and directors owned a median $1.83 \%$ of their firm's shares. The sample firms had a median of 2.0 blockholders per firm (\# Blockholders) and median total blockholder share ownership (Blockholders) was 21.1\%. Blockholders are shareholders who own 5\% or more of firm's common stock. Additionally, 20.6\% of the sample firms had a dual leadership structure (Dual LS). A dual leadership structure occurs when different people hold the CEO and Chairman of the Board positions in a firm.

\section{EMPIRICAL ANALYSIS}

In Table II, the quarterly dividend increases that occurred from the first quarter of 2001 through the fourth quarter of 2003 are analyzed. ${ }^{2}$ The seasonal pattern of dividend increases noted by Benartzi, Michaely and Thaler is also apparent for the sample firms used in this study. There were 124 dividend increases by the sample firms in the first quarter and 92 dividend increases in the fourth quarter of the sample years (see Panel B of Table II). Each of these numbers is larger than the number of dividend increases in the second or third quarters of the sample years. Also, the 43 dividend increases that occurred in the fourth quarter of 2003 is more than the number of dividend increases that occurred in the fourth quarter of 2001 or 2002. Similarly, the number of dividend increases in the third quarter of 2003 (36) is more than the number of dividend increases that occurred in the third quarter of either 2001 or 2002. The 79 firms that increased their dividends in the last two quarters of 2003 includes 18 firms that initiated dividend payments in the third or fourth quarters of $2003 .{ }^{3}$ This is $14 \%$ of the 127 firms that did not pay a dividend in the second quarter of 2003 and is very close to the $13 \%$ of the nondividend paying firms in the Brav, et al. survey that said the dividend tax change definitely or probably would lead them to initiate dividends.

The above pattern of dividend increases is also evident in the second quarter of 2003 as more firms increased their dividends in that quarter than in the second quarter of the two previous years. However, the rise in the number of firms increasing their dividend payments is less pronounced in the second quarter of 2003 than it is for subsequent quarters. These results suggest that some firms reacted to the change in dividend taxation in the second quarter of 2003, but the full effect of the dividend tax reduction did not become evident until the third quarter of that year. The previous pattern of dividend increases does not hold for the first quarter of 2003, as the 42 dividend increases in that quarter are less than the 45 dividend increases recorded in the first quarter of 2001 but more than the 37 dividend increases that occurred in the first quarter of 2002.

In Panel C of Table II, the percentage of sample firms increasing their dividends in each quarter of 2003 is compared to the comparable figure from 2002. In the fourth quarter of $2003,12.4 \%$ of sample firms increased their dividends versus the $7.5 \%$ of sample firms that did so in the fourth quarter of 2002 . The $4.9 \%$ difference in the percentage of firms increasing their dividends is significant at the 5\% level ( $\mathrm{z}$ value $=2.52$ ). Similarly, the $10.3 \%$ of sample firms that increased their dividends in the third quarter of 2003 is more than the $5.7 \%$ of sample firms that did so in the corresponding quarter of 2002 . The $4.6 \%$ difference in the percentage of firms increasing their dividends is significant at the $1 \%$ level $(\mathrm{z}$ value $=2.59$ ). In the second quarter of $2003,2.6 \%$ more firms increased their dividends than did so in the second quarter of 2002, however, the difference is not statistically significant. Additionally, there is no significance between the percentage of firms increasing their dividends in the first quarter of 2003 and those that did so in the first quarter of 2002. The above results indicate that some firms did increase the amount of their dividend payments in response to the dividend tax reduction, but the response was not overwhelming.

In the last two columns of Panel A in Table II there is also some weak evidence that the magnitude of the dividend increases also changed following the dividend tax reduction. The median dividend increase in the fourth quarter of 2003 (\$.04) was almost twice as great as the median dividend increase in the fourth quarter of 2002(\$.023). Similarly, the median dividend increase in the third quarter of 2003 (\$.02) was twice as large as the median dividend increase in the third quarter of 2002 (\$.01). The same pattern holds for the mean dividend increases but is less pronounced. None of the differences in median or mean dividend increases is statistically significant.

In Table III, the dividend payments of all the sample firms are analyzed. The mean per share dividend payment (DPS) of the sample firms increased slightly over the sample period from $\$ .1236$ in the first quarter of 2001 to .1279 in the fourth quarter of 2003 (Panel A). The mean change in dividends per share ( $\triangle \mathrm{DPS}$ ) was $\$ .0047$ in the fourth quarter of 2003 and $\$ .0057$ in the third quarter of 2003. The dividend change in the third quarter of 2003 is 
significant at the $5 \%$ level $(\mathrm{z}$ value $=2.07$ ). The mean dividend increase in those two quarters was much higher than the dividend change (\$.0029) in the quarter with the next highest mean dividend increase (the fourth quarter of 2002). Additionally, none of the other quarters had a statistically significant dividend increase. The only other quarter with a statistically significant dividend change was the second quarter of 2001 when the mean dividend payment of the sample firms decreased by $-\$ .0062$. In Panel B, the quarterly dividend changes in 2003 are compared to those in the corresponding quarter of 2002. The mean dividend change in the third quarter of 2003 was $\$ .0046$ higher that the mean dividend change in the third quarter of 2002. The difference in mean dividend change is significant at the $1 \%$ level ( $\mathrm{z}$ value $=3.17$ ). The dividend change in the fourth quarter of 2003 was also higher the dividend change in the fourth quarter of 2002, but the difference is not statistically significant. The results presented thus far from Table III confirm those presented in Table II and indicate that the dividend tax reduction did cause some firms to increase their dividend payments.

Executive surveys and previous empirical studies have found a number of other factors that affect firm dividend payments and, therefore, could be driving the above results. One alternate explanation for the observed dividend increases is that the firms are increasing their dividend payments in response to an increase in earnings. Lintner found that "net earnings were the predominate element which determined current changes in dividends." This was confirmed by the Brav, et al. survey. Further, numerous studies, including Benartzi, Michaely, Thaler (1997), Healy and Palepu (1988) and DeAngelo, De Angelo, and Skinner (1992), have found that dividend payments are highly positively correlated with firm earnings. To ascertain if increases in earnings could be driving the above results the mean EPS and ROE are calculated for the sample firms from 2001 through 2003. Looking first at EPS, the median EPS of the sample firms increased each year during the sample period, from \$1.13 in 2001 to \$1.46 in 2003. Median ROE also increase monotonically during the period, from .113 in 2001 to .131 in 2003. As an additional test, the sample firms were divided into two subgroups, firms that increased their dividends in the third or fourth quarters of 2003 (79 firms) and those that did not (269 firms). ${ }^{4}$ The mean EPS and ROE was calculated for each subgroup of firms (see panel B of Table IV). Firms that increased their dividends after the dividend tax reduction had mean EPS of $\$ 1.87$ in 2002 while firms that did not increase their dividends had mean EPS of \$.96. Similarly, ROE in 2002 was $16.9 \%$ for the dividend increase firms versus $10.4 \%$ for the no dividend increase firms. The same pattern holds for 2003 as well as firms that increased their dividends after the dividend tax reduction had mean EPS of \$2.54 in 2003 while firms that did not increase their dividends had EPS of \$1.33. Additionally, the mean ROE in 2003 was $20.0 \%$ for the dividend increase firms versus $5.9 \%$ for the no dividend increase firms. Obviously, enhanced earnings could be driving the previously reported results.

Lintner and Brav, et al. also found that the stability and sustainability of earnings were also important determinants of firm dividend changes. For example, Lintner observes that "most managers sought to avoid making changes in their dividend rates that might have to be reversed." Brav, et al. also noted the "extreme reluctance on the part of management to cut dividends" as evidenced by the $93.8 \%$ of financial executives surveyed who strongly agreed or agreed that they try to avoid reducing dividends. They also found that $71.9 \%$ of financial executives of dividend paying companies considered stability of future earnings a very important or important factor affecting a firm's dividend decision. Additionally, $67.1 \%$ of those financial executives considered a sustainable change in earnings a very important or important factor affecting a firm's dividend decision. The standard deviation of EPS ( $\sigma$ of EPS) from 1993 to 2002 was used to measure the earnings stability of the sample firms. Consistent with Lintner and Brav, et al., the dividend increase firms had a mean standard deviation of EPS of 1.03 versus 1.26 for the no dividend increase firms. These results suggest that earnings stability may have been a factor in the sample firms' dividend decisions. Another factor that has been shown to affect a firm's dividend decision is firm size (see Fama and French (2001)). It is generally believed that larger firms have better access to credit markets than smaller firms and, therefore, are better able to cover with additional borrowings any earnings shortfall that would endanger their ability to maintain their current dividend payment. Consequently, larger firms, everything else the same, might be more willing to increase their dividend payments than smaller firms. When size is measured by total assets (Assets), the dividend increase firms are seen to be slightly larger that the no dividend increase firms. With the former group having mean total assets of $\$ 14.8$ billion as compared to $\$ 13.9$ billion for the no dividend increase firms (Panel A of Table IV). If size is measured by the market value of the firm's common equity (MV Eq), the dividend increase firms are seen to be considerably larger than the no dividend increase firms (mean MV Eq of $\$ 15.2$ billion versus $\$ 10.5$ billion). 
The investment opportunities available to a firm has also been shown to affect a firm's dividend decision (see Fama and French (2001)). Survey results from Brav, et al. support this finding as $47.6 \%$ of financial executives surveyed said the availability of good investment opportunities was a very important or important factor affecting their firm's dividend decision. Two proxies for investment opportunities are used, the first is a firm's growth rate in sales from 1993 to 2002 (Sales Growth). Consistent with Fama and French and Brav et al., the 75.6\% growth rate in sales for the dividend increase firms is less than the $86.9 \%$ rate for the no dividend increase firms. If growth opportunities are measured by a firm's market to book value of equity (Mkt to Book), the dividend increase firms seem to actually have more investment opportunities than the no dividend increase firms. The mean market to book ratio for the dividend increase firms is 3.04 as compared to 1.83 for the no dividend increase firms.

\section{Logit Regression}

A logit regression analysis is employed to ascertain if the above factors are causing the previously discussed dividend increases in the third and fourth quarters of 2003. In each of the regressions, the dependent variable takes on a value of one if a firm increased its dividend during the specified quarter and zero otherwise. The results of these regressions are contained in Table V. A number of control variables are used in these regressions. The natural $\log$ of the market value of the firms common equity (LMV Eq) is used as the proxy for firm size. Earnings per share of the firm for the year in which a quarterly dividend change is calculated $\left(\mathrm{EPS}_{0}\right)$ and earnings per share in the previous year $\left(\right.$ EPS $\left._{-1}\right)$ are employed to account for the effect of firm earnings on the firm's dividend changes. The standard deviation of EPS from 1993 to 2002 ( $\sigma$ of EPS) is used to measure earnings stability and growth rate in sales over the same time period (Sales Growth) is included to account for firm investment opportunities. Industry effects in the sample data are accounted for by using a dummy variable for each of the seven industries which contain the largest number of sample firms. Industries are grouped by three digit SIC codes. The main variable of interest is a dummy variable (Tax Chg) that takes on a value of one if the dividend change is for the third or fourth quarter of 2003 and zero otherwise. If the coefficient on this variable is positive, that implies that the change in dividend taxation caused an increase in the probability that the sample firms would increase their dividend payments in the specified quarter.

In the first regression in Table V, data for the sample firms from the fourth quarters of 2002 and 2003 was used. The second regression contains data from the third quarters of 2002 and 2003 and the last regression contains data from the third and fourth quarters of 2002 and 2003. The results from the three regressions are generally consistent. In each of the three regressions, the coefficient on LMV Eq is positive and is statistically significant at the $1 \%$ level in two of the regressions. This indicates that the larger the firm, the more likely the firm was to increase its dividend payment. The coefficients on $\mathrm{EPS}_{0}$ were positive in each regression and every coefficient was significant at the $10 \%$ level or better. These findings are consistent with the results of previous empirical studies and surveys that have found that current year earnings are highly positively correlated with dividend changes. However, the coefficients on the previous year's earnings (EPS $)_{-1}$ have inconsistent signs and are never statistically significant. The coefficients on $\sigma$ of EPS are negative and significant at the 5\% level or better in each regression. This implies that the more unstable a firm's earnings are the lower the probability the firm will increase its dividend payment. These findings confirm the survey results of Lintner and Brav, et al. that showed that earnings stability is an important determinant of a firm's willingness to increase its dividend.

The coefficient on Sales Growth is negative in all three regressions and significant at the $1 \%$ and $10 \%$ levels in two of the regressions. Consistent with the survey results from Brav, et al., this suggests that the more investment opportunities a firm has the less likely they are to increase their dividends. Lastly, the coefficient on Tax Chg is positive in all three regressions and significant at the $10 \%$ level or better in each regression. This confirms our previous results and indicates that after controlling for the other factors mentioned previously, the dividend tax rate change did increase the probability that a firm would increase its dividend payment in the third and fourth quarters of 2003. Based on the coefficients from the first regression in Table V, the dividend tax reduction increased by $4.2 \%$ the probability that the average firm in the sample would increase its dividend payment in the fourth quarter of 2003. Further, the coefficients from the second regression indicate that the dividend tax reduction increased by $3.7 \%$ the probability that the average sample firm would increase its dividend payment in the third quarter of 2003. 


\section{Ownership And Leadership Structure}

The above results indicate that while some firms responded to the dividend tax reduction by increasing their dividend payments, many did not. Next, it will be ascertained if a firm's ownership and leadership structure affected the firm's dividend payment decision. One of the principle tenets of agency theory is that significant share ownership by certain groups and individuals gives them the financial incentive to act in the best interest of the other shareholders of the firm. Among the individuals and groups believed to motivated by share ownership in the firm are the CEO, other officers and directors, and blockholders (see Fama (1980), Fama and Jensen (1983), and Schliefer and Vishny (1996)). However, with respect to the dividend tax reduction, the interests of tax-exempt blockholders like mutual funds and pension funds may be different from the interests of the taxable investors in those institutions. Since these institutional blockholders are tax-exempt, they do not directly benefit from the dividend tax reduction but would incur additional brokerage fees and other costs if they had to reinvest the increased dividends paid by the companies whose shares they own. As a consequence, they might prefer to avoid those costs by seeking to have the firms they invest in not increase their dividend payments. Additionally, a dual leadership structure has also been suggested as a way to control the agency problems faced by many firms (see Rechner and Dalton (1991)). A dual leadership structure occurs when different people hold the CEO and Chairman of the Board positions. Separating the two positions is believed to make it harder for one person to take actions that are not in the best interest of the firm's shareholders. In this context, this implies that a dual leadership structure should be associated with a greater likelihood that a firm will increase its dividend payment after the dividend tax reduction.

In Panel A of Table VI the means of several ownership and leadership structure variables are presented for firms that increased their dividends in the third or fourth quarters of 2003 and for those that did not. Contrary to agency theory predictions, firms that increased their dividends had lower share ownership by their CEOs and other officers and directors (Oth O\&D) than firms that did not. However, none of those differences in share ownership was statistically significant. Firms that increased their dividends also had a smaller number of blockholders (\# Blockholders) and lower blockholder share ownership (Blockholders) than firms that did not. The difference in blockholder share ownership is significant at the $5 \%$ level $(\mathrm{z}$ value $=2.28)$. The latter result suggests that blockholders generally did not want firms to increase their dividend payments following the dividend tax reduction. Lastly, $16.7 \%$ of firms that increased their dividend payments had a dual leadership structure while $21.8 \%$ of firms that did not increase their dividends had a dual leadership structure. The $5.1 \%$ difference is not statistically significant.

As a further test, the ownership and leadership structure variables are used as independent variables in a logit regression analysis. The results of this analysis are contained in Panel B of Table VI. The dependent variable in the regression takes a value of one if the firm increased its dividend in either the third or fourth quarter of 2003 and zero otherwise. Consistent with the above results, the coefficient on blockholders' share ownership (Block) is negative and significant at the $10 \%$ level. This result confirms that the greater the share ownership by blockholders the less likely the firm was to increase its dividend payment after the dividend tax reduction. One possible explanation of this result is that most blockholders are tax-exempt institutional investors that did not wish to incur the additional costs associated with investing the extra dividend income. None of the coefficients on the other ownership and leadership structure variables are statistically significant.

\section{Robustness}

In the logit regression analysis used in this study, several additional variables were tried as control variables (not shown). These include using total assets as a size proxy in place of the market value of equity and employing ROE instead of EPS as the firm earnings measure. The market to book value of common equity and the change in net property, plant, and equipment were also used as the investment opportunities proxy in place of the growth rate in sales. The total debt to total assets ratio was also tried as a proxy for the fixed financial obligations of the firm. In each case, the alternate/additional variables employed either lacked explanatory power or did not materially affect the results previously presented. 


\section{CONCLUSION}

With the passage of the Jobs and Growth Reconciliation Act of 2003, the maximum tax rate on dividend income was lowered from $38.6 \%$ to $15 \%$. This eliminated the traditional tax disadvantage that dividend income had relative to capital gains income. Theoretically, this should have led a significant number of firms to increase their dividend payments. However, in response to a survey by Brav, Graham, Harvey, and Michaely (2004) shortly after the passage of the Act, only $30 \%$ of the financial executives of companies currently paying dividends said they probably or definitely would increase dividends as a result of the dividend tax reduction. In an empirical analysis of firm dividend payments after the dividend tax reduction took effect, it was found that there was a statistically significant increase in the number of firms raising their dividends. For example, in the third quarter of 2003, 4.6\% more firms increased their dividends than did so in the third quarter in 2002. Similarly, $4.9 \%$ more firms increased their dividend payments in the fourth quarter of 2003 than did so in the fourth quarter of 2002. A logit regression analysis of dividend changes showed that most of the change in the number of dividend increases was caused by the dividend tax reduction and not other factors such as earnings, earnings stability, investment opportunities or firm size. The logit regression analysis also indicated that the dividend tax reduction increased by $3.7 \%(4.2 \%)$ the probability that the average sample firm would increase its dividend payment in the third (fourth) quarter of 2003. This relatively weak response to the dividend tax reduction could indicate that, in this instance, managers and directors did not vigorously pursue the interests of their firm's shareholders. It was also found that the greater a firm's blockholder share ownership the less likely the firm was to increase its dividend payment following the dividend tax reduction. CEO and other officer and director share ownership were found to be unrelated to the probability that a firm would increase its dividend payment.

\section{REFERENCES}

1. Agrawal A. and C. Knoeber. Managerial Compensation and the Threat of Takeover, Journal of Financial Economics, Vol. 47 (1998), 219-39.

2. Amihud, Y. and B. Lev. (1981), Risk reduction as a managerial motive for conglomerate mergers, Bell Journal of Economics, Vol. 12 No. 2, pp. 605-17.

3. Benartzi, S., R. Michaely and R. Thaler. Do Changes in Dividends Signal the Future or the Past?, The Journal of Finance, Vol. 52 (1997), 1007-1034.

4. $\quad$ Black, F. "The Dividend Puzzle, Journal of Portfolio Management, Vol. 2, Winter 1976, 5-8.

5. Brav, A., J. Graham, C. Harvey, and R. Michaely. Payout Policy in the 21st Century, Working Paper, Duke University, June 14, 2004.

6. Core, J., R. Holthausen, and D. Larcker. Corporate Governance, Chief Executive Officer Compensation, and Firm Performance, Journal of Financial Economics, 51 (1999), 371-406.

7. DeAngelo, H., L. DeAngelo and D. Skinner. Dividends and Losses, The Journal of Finance, Vol. 47 (1992), 1837-63.

8. Fama, E. Agency Problems and the Theory of the Firm, Journal of Political Economy, Vol. 88 (1980), 288307.

9. Fama, E, and K. French. Disappearing Dividends: Changing Firm Characteristics or Lower Propensity to Pay, Journal of Financial Economics, Vol. 60 (2001), 3-43.

10. Fama, E. and Jensen, M. Separation of Ownership and Control, Journal of Law and Economics, Vol. 26 (1983), 301-325.

11. Healy, P. and K. Palepu. Earnings Information Conveyed by Dividend Initiations and Omissions, Journal of Financial Economics, Vol. 21 (1988), 149-75.

12. Jensen, M. and W. Meckling. Theory of the Firm: Managerial Behavior, Agency Costs and Ownership Structure, Journal of Financial Economics, Vol. 3 (1976), 305-360.

13. Nissim, D. and A. Ziv. Dividend Changes and Future Profitability, The Journal of Finance, Vol. 56 (2001), 2111-2133.

14. Rechner, P. and D. Dalton. CEO Duality and Organizational Performance: A Longitudinal Analysis, Strategic Management Journal, 12 (1991), 155-160. 


\section{Footnotes}

1. All survey responses from Brav, et al. cited in this study are from the subsample of firms currently paying dividends, unless stated otherwise.

2. A comparison to dividend increases that occurred prior to 2001 was not attempted as the results would likely be biased by the marked decrease in firm dividend payments since the late 1970s noted by Fama and French (2001).

3. The mean dividend payment for the six firms that initiated dividends in the third quarter of 2003 was $\$ .272$ and was $\$ .188$ for the twelve firms that initiated dividends in the fourth quarter of 2003.

4. The no dividend increase subsample includes 16 firms that cut their dividends in the third or fourth quarters of 2003.

\section{Table I}

Summary Statistics for Selected Variables for 2002

Assets is the total assets of the company and $M V E q$ is the market value of the firm's common equity. Debt is the total debt to total assets ratio and Sales Growth is the growth in firm sales from 1993 through 2002. Mkt to Book is the market value of the firm's common equity divided by the book value of common equity. EPS is earnings before extraordinary items per share and $R O E$ is earnings before extraordinary items divided by the book value of common equity. $\sigma$ of EPS is the standard deviation of EPS from 1993 to 2002. CEO, Oth $O \& D$, and Blockholders are the percentage of the firm's common stock owned by the chief executive officer, other officers and directors, and blockholders, respectively. \# Blockholders is the number of blockholders who own stock in the firm and Dual $L S$ is the percentage of firms with a dual leadership structure.

Panel A: Size, Capital Structure, etc.

\begin{tabular}{lrrr}
\hline & $\underline{\text { Mean }}$ & $\frac{\text { Median }}{3,709}$ & $\frac{\text { S. Dev. }}{43,414}$ \\
Assets $(\$ M)$ & 14,091 & 3,177 & 27,834 \\
MV Eq (\$M) & 11,572 & .284 & .169 \\
Debt & .288 & 65.6 & 93.8 \\
Sales Growth $(\%)$ & 2.106 & 2.281 & 16.32 \\
Mkt to Book & & \\
\hline
\end{tabular}

Panel B: Profits and Stability

\begin{tabular}{llcc}
\hline & Mean & $\frac{\text { Median }}{1.33}$ & $\frac{\text { S. Dev. }}{3.36}$ \\
EPS & 1.17 & .791 & 1.22 \\
o of EPS & 1.20 & .116 & .910 \\
ROE & .119 & .16 & .96 \\
\hline
\end{tabular}

Panel C: Ownership and Leadership Structure

\begin{tabular}{lccc}
\hline & Mean & $\frac{\text { Median }}{.82}$ & $\frac{\text { S. Dev. }}{6.10}$ \\
CEO (\%) & $\frac{1.45}{4.47}$ & 1.83 & 7.25 \\
Oth O\&D (\%) & 2.38 & 2.00 & 1.58 \\
\# Blockholders & 22.7 & 21.1 & 16.2 \\
Blockholders (\%) & 20.6 & & \\
Dual LS (\%) & &
\end{tabular}


Table II

Dividend Increases from 2001 to 2003

Panel A: Dividend Increases by Year and Quarter

\begin{tabular}{|c|c|c|c|c|c|}
\hline \multirow[b]{2}{*}{$\underline{\text { Year }}$} & \multirow[b]{2}{*}{ Qtr. } & \multirow[b]{2}{*}{ No. } & \multicolumn{3}{|c|}{ Dividend Increases (\$) } \\
\hline & & & $\%$ & Med & Mean \\
\hline 2003 & 4 & 43 & $1 \overline{2.4}$ & .040 & .079 \\
\hline$"$ & 3 & 36 & 10.3 & .020 & .063 \\
\hline$"$ & 2 & 35 & 10.1 & .020 & .039 \\
\hline$"$ & 1 & 42 & 12.1 & .010 & .079 \\
\hline 2002 & 4 & 26 & 7.5 & .023 & .077 \\
\hline$"$ & 3 & 20 & 5.7 & .010 & .058 \\
\hline$"$ & 2 & 26 & 7.5 & .012 & .055 \\
\hline$"$ & 1 & 37 & 10.6 & .010 & .071 \\
\hline 2001 & 4 & 23 & 6.6 & .040 & .102 \\
\hline$"$ & 3 & 21 & 6.0 & .010 & .053 \\
\hline$"$ & 2 & 27 & 7.8 & .014 & .025 \\
\hline " & 1 & 45 & 12.9 & .010 & .066 \\
\hline
\end{tabular}

Panel B: Dividend Increases by Quarter

$\begin{array}{lllll}\text { Number of Div Incr } & \underline{\mathbf{Q 1}} & \frac{\mathbf{Q 2}}{88} & \frac{\mathbf{Q 3}}{77} & \frac{\mathbf{Q 4}}{92}\end{array}$

Panel C: Comparison of Dividend Increasing Firms in 2003 to 2002 (\%)

\begin{tabular}{ccccc} 
& $\mathbf{2 0 0 3}$ & $\frac{\mathbf{2 0 0 2}}{7.5}$ & $\frac{\text { Difference }}{4.9^{\mathrm{b}}}$ & $\frac{\underline{\mathbf{Z} \text { Value }}}{2.52}$ \\
Q4 & 12.4 & 5.7 & $4.6^{\mathrm{c}}$ & 2.59 \\
Q3 & 10.3 & 7.5 & 2.6 & 1.29 \\
Q2 & 10.1 & 10.6 & 1.5 & 0.61 \\
\hline
\end{tabular}

$\mathrm{a}=$ significant at the $10 \%$ level.

$\mathrm{b}=$ significant at the $5 \%$ level.

$\mathrm{c}=$ significant at the $1 \%$ level. 


\section{Table III}

Dividend Payments for All Sample Firms from 2001 to 2003

$D P S$ is the per share dividend paid in the indicated quarter and $\triangle D P S$ is the change in DPS from the previous quarter. EPS is earnings before extraordinary items per share and $R O E$ is earnings before extraordinary items divided by the book value of common equity.

Panel A: Dividend Payments and Changes (\$)

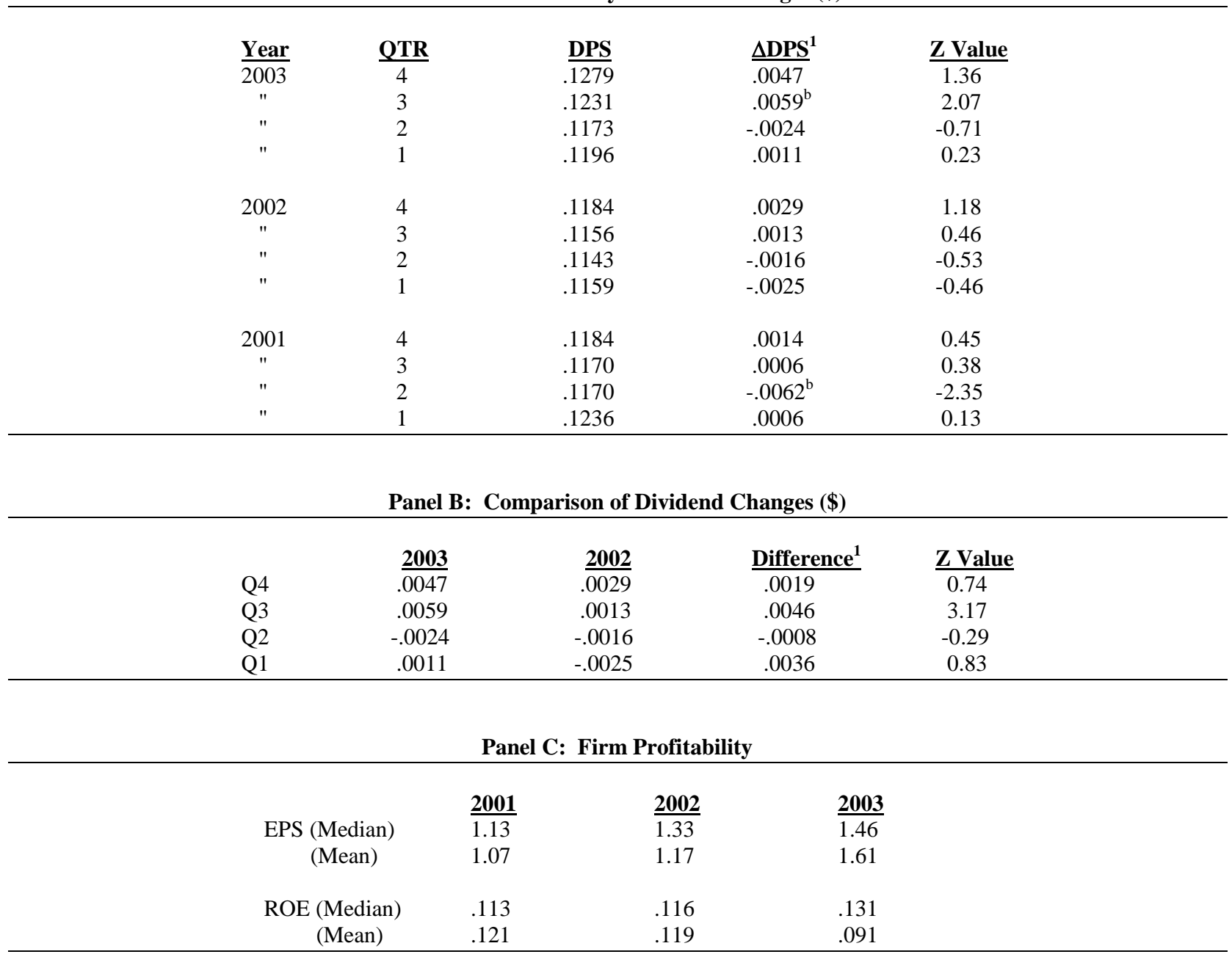

1. Rounding may cause this column not to sum.

$\mathrm{a}=$ significant at the $10 \%$ level.

$\mathrm{b}=$ significant at the $5 \%$ level.

$\mathrm{c}=$ significant at the $1 \%$ level. 


\section{Table IV}

Comparison of Dividend Increasing and Non-Increasing Firms in 2002

Assets is the total assets of the company and $M V E q$ is the market value of the firm's common equity. Debt is the total debt to total assets ratio and Sales Growth is the growth in firm sales from 1993 through 2002. Mkt to Book is the market value of the firm's common equity divided by the book value of common equity. EPS is earnings before extraordinary items per share and $R O E$ is earnings before extraordinary items divided by the book value of common equity. $\sigma$ of EPS is the standard deviation of EPS from 1993 to 2002. Div Incr is the subsample of firms that increased their dividends in the third or fourth quarter of 2003 and No Incr are the firms that did not.

Panel A: Size, Capital Structure, etc.

\begin{tabular}{|c|c|c|c|}
\hline & Div Incr & No Incr & Difference \\
\hline Assets (\$M) & $\overline{14,827}$ & 13,875 & 952 \\
\hline MV Eq (\$M) & 15,216 & 10,502 & 4,714 \\
\hline Debt & .293 & .287 & .006 \\
\hline Sales Growth (\%) & 75.6 & 86.9 & -11.3 \\
\hline Mkt to Book & 3.04 & 1.83 & 1.21 \\
\hline
\end{tabular}

Panel B: Profitability and Stability

\begin{tabular}{lccc}
\hline & Div Incr & $\frac{\text { No Incr }}{0.96}$ & $\frac{\text { Difference }}{0.91}$ \\
EPS & 1.87 & 1.26 & -.23 \\
$\sigma$ of EPS & 1.03 & .104 & .065 \\
ROE & .169 &
\end{tabular}


Table V

\section{Logit Regression Analysis of Dividend Increases}

The dependent variable is a dummy variable that takes on a value of one if a firm increased its dividend in the indicated quarter and zero otherwise. $L M V E q$ is the natural $\log$ of the market value of the firm's common equity. EPS is earnings before extraordinary items per share and $\sigma$ of EPS is the standard deviation of EPS from 1993 to 2002. Sales Growth is the growth in firm sales from 1993 through 2002. Tax Chg is a dummy variable that takes on a value of one in the third or fourth quarter of 2003 and zero otherwise. Industry represents dummy variables for the seven three digit SIC code industries with the largest number of sample firms. $\mathrm{P}$ values are in parenthesis under the coefficients.

\begin{tabular}{|c|c|c|c|}
\hline Intercept & $\begin{array}{l}\frac{\mathbf{Q 4}}{-5.47^{\mathrm{c}}} \\
(.000)\end{array}$ & $\frac{\mathbf{Q 3}}{-1.96^{\mathrm{a}}}$ & $\begin{array}{r}\mathbf{Q 3 + Q 4} \\
-3.91^{\mathrm{c}} \\
(.000)\end{array}$ \\
\hline LMV Eq & $\begin{array}{c}.386^{\mathrm{c}} \\
(.000)\end{array}$ & $\begin{array}{c}.002 \\
(.986)\end{array}$ & $\begin{array}{l}.214^{\mathrm{c}} \\
(.005)\end{array}$ \\
\hline $\mathrm{EPS}_{0}$ & $\begin{array}{c}.206^{\mathrm{b}} \\
(.026)\end{array}$ & $\begin{array}{l}.218^{\mathrm{a}} \\
(.080)\end{array}$ & $\begin{array}{l}.214^{\mathrm{c}} \\
(.003)\end{array}$ \\
\hline $\mathrm{EPS}_{-1}$ & $\begin{array}{l}-.044 \\
(.591)\end{array}$ & $\begin{array}{c}.035 \\
(.766)\end{array}$ & $\begin{array}{l}-.022 \\
(.741)\end{array}$ \\
\hline$\sigma$ of EPS & $\begin{array}{l}-.372^{b} \\
(.035)\end{array}$ & $\begin{array}{l}-.803^{c} \\
(.001)\end{array}$ & $\begin{array}{c}-.532^{c} \\
(.000)\end{array}$ \\
\hline Sales Growth & $\begin{array}{l}-.027 \\
(.863)\end{array}$ & $\begin{array}{l}-.617^{c} \\
(.007)\end{array}$ & $\begin{array}{l}-.230^{\mathrm{a}} \\
(.079)\end{array}$ \\
\hline Tax Chg & $\begin{array}{l}.474^{\mathrm{a}} \\
(.088)\end{array}$ & $\begin{array}{l}.624^{\mathrm{b}} \\
(.043)\end{array}$ & $\begin{array}{l}.534^{\mathrm{c}} \\
(.009)\end{array}$ \\
\hline Industry & Yes & Yes & Yes \\
\hline$\chi^{2}$ & $44.5^{\mathrm{c}}$ & $43.3^{\mathrm{c}}$ & $60.3^{c}$ \\
\hline $\mathrm{N}$ & 602 & 602 & 1204 \\
\hline
\end{tabular}




\section{Table VI}

Ownership and Leadership Structure in 2002

$C E O$, Oth $O \& D$, and Blockholders are the percentage of the firm's common stock owned by the chief executive officer, other officers and directors, and blockholders, respectively. \# Blockholders is the number of blockholders who own stock in the firm and Dual $L S$ is the percentage of firms with a dual leadership structure.

The dependent variable in the logit regression is a dummy variable that takes on a value of one if a firm increased its dividend in the third or fourth quarter of 2003 and zero otherwise. $L M V E q$ is the natural log of the market value of the firm's common equity. EPS is earnings before extraordinary items per share and $\sigma$ of EPS is the standard deviation of EPS from 1993 to 2002. Sales Growth is the growth in firm sales from 1993 through 2002. Industry represents dummy variables for the seven three digit SIC code industries with the largest number of sample firms. P values are in parenthesis under the coefficients.

Panel A: Share Ownership

\begin{tabular}{lcccc}
\hline & Div Incr & $\frac{\text { No Incr }}{2.45}$ & $\frac{\text { Difference }}{-.02}$ & $\frac{\text { Z Value }}{-0.03}$ \\
CEO $(\%)$ & $(0.68)$ & $(0.86)$ & & \\
Oth O\&D (\%) & 3.83 & 4.66 & -.83 & -1.04 \\
& $(1.57)$ & $(1.92)$ & & -1.63 \\
\# Blockholders & 2.13 & 2.46 & -.33 & \\
& $(2.00)$ & $(2.00)$ & & $-2.28^{\mathrm{b}}$ \\
Blockholders (\%) & 19.2 & 23.7 & -4.5 & \\
& $(16.0)$ & $(22.4)$ & & -1.01 \\
\hline
\end{tabular}

Panel B: Logit Regression Analysis

\begin{tabular}{|c|c|c|c|c|c|c|}
\hline $\begin{array}{l}\text { Interc } \\
-2.86^{6} \\
(.022)\end{array}$ & $\begin{array}{c}\frac{\text { LMV Eq }}{.273^{\mathrm{b}}} \\
(.040)\end{array}$ & $\begin{array}{l}\frac{\mathbf{E P S}}{\mathbf{0}}^{\underline{1}} \\
(.076)\end{array}$ & $\begin{array}{l}\frac{\text { EPS }_{-1}}{.014} \\
(.877)\end{array}$ & $\begin{array}{c}\frac{\boldsymbol{\sigma} \text { of EPS }}{-.432^{\mathrm{b}}} \\
(.018)\end{array}$ & $\begin{array}{l}\text { Sales Gr } \\
-.149 \\
(.412)\end{array}$ & $\begin{array}{l}\text { CEO } \\
.037 \\
(.228)\end{array}$ \\
\hline$\frac{\text { Oth O\&D }}{.014}$ & $\begin{array}{l}\text { \# Block } \\
.245 \\
(.230)\end{array}$ & $\begin{array}{l}\text { Block } \\
-.041^{\mathrm{a}} \\
(.075)\end{array}$ & $\begin{array}{l}\frac{\text { Dual }}{-.408} \\
(.295)\end{array}$ & $\frac{\text { Industry }}{\text { Yes }}$ & $\begin{array}{l}\frac{\chi^{2}}{42.5^{\mathrm{c}}} \\
(.000)\end{array}$ & $\frac{\mathbf{N}}{297}$ \\
\hline
\end{tabular}

$\mathrm{a}=$ significant at the $10 \%$ level.

$\mathrm{b}=$ significant at the $5 \%$ level.

$\mathrm{c}=$ significant at the $1 \%$ level. 
NOTES 